\title{
The Employee Performance Influenced by Communication: a Study of BUMD in Indonesia
}

\author{
Syamsul Hadi Senen, Masharyono, Nida Triananda, Sumiyati \\ Universitas Pendidikan Indonesia \\ masharyono@upi.edu
}

\begin{abstract}
In today world, communication is an important component of organizational activity. This study was conducted to see how big the influence of communication on the employee performance. The kind of research is descriptive and verification with samples from 89 employees, by using technique analysis simple linear regression. based on results of the research uses linear regression analysis simple, obtained the results of that there is the influence between communications against the employee performance. The difference this research with another research situated at the object of research, measurement instruments used, times research and the results of research. In this research using the theory of journals and books, so the theory used different.
\end{abstract}

Keywords-Communication, lateral communication, upward comuunication, downward communication. employee performance , quality of work, quantity of work, BUMD

\section{INTRODUCTION}

The low of employee's performance in the era of competitive and this is still an issue major in management human resources. The employee performance effective be essential to continue to be improved in order to organization to achieve the objective of business [1] The low performance employees are priority faced by company now, so that maximize the performance be the main challenges of any organization [2][3][4].

The employee performance problems it faced by companies in various sectors in many countries, either moving in a public sector and private, in health institutions, education, banking, companies belonging to the country, until small companies, hence maximize the employee performance. Become major challenge for any organization to be able to use available resources even more efficiently and effectively in order to maintain competitiveness [5][6][7][8][9]

Has many studies empirical and theoretical regarding performance given the importance of to increase the employee performance. The employee performance is crucial in the company's effort to achieve its goal business and become one of the main factors the success of an enterprise. [10] Human being is resources very important in organization, because people support organization through work, creativity, and the role of real as that can be seen in any organization. The company performance be reflected by the performance of his servants or in other words, performance is concrete results that could be observed and can be measured, [11] The employee performance it can be seen through assesses the work someone, the employee performance should be formulated. That can be used as yardstick towards achieving a person from the responsibility to him [12].

Organization means communicating with employees reflected in spirit, motivation and the employee performance, there are seven factors that can affect the employee performance of them: 1 ) the quality of work, 2 ) skill , 3 ) responsiveness of, 4 ) the speed, 5 ) initiative, 6 ) the ability, 7 ) communication [13]

Previous research [14] In research she revealed that effective communication create an atmosphere of mutual understand between superiors with employees, when communication that there is in bad condition and will affect the employee performance. he findings similar in research conducted by [15] that communication work to work effectively satisfaction. The satisfaction would eventually be led to the high performance on those.

According to the analysis of the above conditions, so low the employee performance an organization or company caused by communication work interwoven in it. This needs to be improved because, in practice organization, effective communication is a requirement on good cooperation to an end organization. Communication is the main force in forming organization. Dynamic communication makes a system cooperation in the organization and connected the organizational goal people participation in it. Good communication can be a proper to increase the employee performance. Through communication, employees to seek counsel from a superior on the implementation of the work. Through communication also employees to be cooperative and pull equal to each other [16]. Any organization prosecuted always can keep employees showing a good performance and maintain employees to dedicate themselves to organization by which they work [17]. When problem's performance was left it threatened to sustainability activity company.

The purpose of this research is to look at an image the employee performance and communication work as well as to see the impact of communication working improves the employee performance.

\section{LITERATURE REVIEW}

Communication employment was the process delivery or acceptance a message from one person to another person, either directly or indirectly, in writing, orally or language nonverbal, [18]. [19] said the communication is the process of shipping 
and acceptance of symbol to the attached. Communication dimensions according to [20] is downward communication, upward communication and lateral communication.

While the performances of employees are real behavior shown every person as work performance produced by employees in accordance with their in the company [11]. Sustainability an organization one of them depends on performance his servants, so the achievement of a goal organization will be less than effective when many employees who are performed well [21]. Dimensions the employee performance used to measure the employee performance in research is based on [22] there are quality of work, quantity of work, interpersonal effectiveness and competency.

The approach that was used in solving the problem of research is the concept of the organization behaves. The organization behaves is a discipline of sciences, which aimed to understand the behavior of individual and group, the process of interpersonal, as well as the dynamics of organization with the aim of enhancing organizational performance and people in it [19].

\section{RESEARCH METHODS}

This research analyzed about the influence of communication work of the performance of employees in BUMD using analysis technique's simple linear regression. In this research for measuring communication work is measured by dimension's downward communication, upward communication and lateral communication. While for measuring the employee performance measured using dimension of quality of work, quantity of work, interpersonal effectiveness and competence.

The research was conducted in PERUM DAM Tirta Mukti Kab. Cianjur to 89 employees., by spreading the questionnaire. Research methodology used the cross-sectional method with the kind of research descriptive and verification. Assuming the research, then method used in research is, explanatory survey aimed at test hypotheses between variables each other variables. Data collection technique used is literature study, observation, interview, and the survey.

\section{RESULTS AND DISCUSSION}

Based on the equation linear regression simple, constant value of 22,414 claimed that if there is no communication, so the size of the employee performance 22,414. The regression coefficient variable communication on employment is 1,018 , which mean the addition of any value occurs communication work will be increasing the employee performance worth 1,018. If a decline in the employee performance, communication work will reduce the employee performance of 1,018 a unit value.

To know the variable influence work communication on variables the employee performance. Points to the value of 0,868 r-square. Based on the calculation on the determination with the formula over hence the determination for communication work against the employee performance is $75,34 \%$. In other words the employee performance influenced
$75,34 \%$ by communication work while 24,66 work \% influenced by other factors outside communication work.

Test the hypothesis in this research is by using test $\mathrm{f}$ (f-test), obtained fhitung value of 266,852 significance with a level of 5 percent. Than the ftabel, point scoring thitung has been much bigger values ftabel $(266,852>1,662)$, so they could take decisions that hypothesis zero (h0) turned down and ha accepted. It means that there is the influence between communication works against the employee performance of PERUM DAM Tirta Mukti Kab. Cianjur.

This means of communication working with the employee performance have a significant / positive .So, been more effectively communication work will the higher the employee performance. This is in accordance with research conducted by [24]. That communication caused level of commitment organization higher and high performance on those.

A discovery that same with the result research [25]. That pleasure communication work with links to the employee performance in an enterprise. [23] Said communication grow motivation to employees with clarify what to do, how well they do it, and how they could be improve the performance. Based on the discussion the, when communication a less well in company resulted in a decreased performance employees. That the company cannot ignore communication between superiors with employees and employees with employees that it would affect positive on the employee performance.

Originality this research found that in BUMD upward communication holds an important role in the effectiveness of communication, while in previous research lateral communication more affect the effectiveness of communication to prove employee performance.

\section{CONCLUSIONS AND RECOMMENDATIONS}

Based on the results of the carried out using descriptive analysis and verification using analysis technique's simple linear regression conclusion that can be taken, the results indicated that communication impact on the employee performance.

The research is expected to help scientists next in conducted research on communication and the employee performance with both indicators different from the theory that more diverse, and against different objects, because there are still many limited in this research, especially with regard to the methodology and engineering data collection.

\section{REFERENCES}

[1] Noe, R. A. Fundamentals of Human Resource Management Fourth. Avenue of the Americas, New York: Doug Hughes.2011.

[2] Khan, R. A. G. Impact of Training and Development on Organizational Performance. Global Journal of Management and Business Research.2011.

[3] Osa, I. G. Monetary Incentives Motivates Employee's On Organizational Performance. Global Journal of Arts Humanities and Social Sciences Vol.2, 2(7), 2014.

[4] Shah, S. S. H. Workload and Performance of Employees. Journal of Contemporary Research in Business, 3(5).2011. 
[5] Esther, M. An analysis of the effect of Corporate Governance on Performance of Commercial State Corporations in Kenya . International Journal of Business and Public Management, 1(1), 6244.2011.

[6] Giri, V. N., \& Pavan Kumar, B. Assessing the impact of organizational communication on job satisfaction and job performance. Psychological Studies, 55(2), 137-143. http://doi.org/10.1007/s12646-010-0013-6. 2010

[7] Imhmed, A. E. Job Satisfaction, Organizational Behavior, and Training to Improve Employees Performance Acase: Public Hospitals - Libya. Journal of Business and Management, 16(8), 7668. 2014.

[8] Lumwagi, N. A Critical Analysis Of Human Resource Management Practices Influencing Performance In Public Universities (Case Study Of Universities In Nairobi C.B.D) . International Journal of Economics, Commerce and Management United Kingdom., II(9), 2014.

[9] Sheehan, M. Human resource management and performance: Evidence from small and medium-sized firms. International Small Business JournalUniversity of Brighton, UK, 32(5), 2014.

[10] Masharyono, \& Senen, S. H. Analisis Job Performance Pegawai Honorer Administrasi Dengan Kompetensi dan Job Characterostics dalam Mendukung Universitas Pendidikan Indonesia Mencapai Leading and Outstanding. Fokus Ekonomi, 10(2), 2015.120-137.

[11] Rivai, V., \& Jauvani, E. Manajemen Sumber Daya Manusia untuk Perusahaan dari Teori ke Praktik. Jakarta: PT Raja Grafindo.2011.

[12] Mulyadi, H. Pengaruh Motivasi dan Kompetensi Kerja Terhadap Produktivitas Kerja Karyawan pada PT. Galamedia Bandung Perkasa. MANAJERIAL, 9(17), 2010. 97-111.

[13] Torang, S. Perilaku Organisasi. Bandung: Alfabeta.2012.

[14] Femi, F. The Impact of Communication on Workers Performance in Selected Organisations in Lagos State , Nigeria, 19(8),2014. 75-82.
[15] Goris, J., Vaught, B., \& Jr, J. P. Effects of Communication Direction on Job Performance and Satisfaction: A Moderated Regression Analysis, 37(October), 2000. http://doi.org/10.1177/002194360003700402 .2000.

[16] Thoha, M. Perilaku Organisasi Konsep Dasar dan Implikasinya. Jakarta: Raja Grafindo Persada.2012.

[17] Masharyono. Pengaruh Job Characteristics terhadap Semangat Kerja Pegawai (Survey pada Pegawai PNS di Lingkungan Disparbud Jabar). Jurnal Riset Akuntansi Dan Keuangan ISSN: 2338-1500,3(3). Retrieved from http://jurnal.upi.edu/artikulasi/view/3804/pengaruh-jobcharacteristics-terhadap-semangat-kerja-pegawai(survey-pada-pegawaipns-di-lingkungan-disparbud-jabar).html 2015.

[18] Usman, H. (Manajemen (Teori, Praktik, dan Riset Pendidikan). Jakarta: Bumi Aksara.2011.

[19] Schermerhorn. Organizational Behavior. United States of America: John Wiley \& Sons. Inc.2010.

[20] Robbins, S. P., \& Judge, T. A. Organizational Behavior. Pearson.2013.

[21] Amilia, S., \& Purnama, R. Pengaruh Kecerdasan Emosional Terhadap Kinerja Pegawai PT. Indonesia Comnets Plus di Bandung. Journal of Business Management and Enterpreneurship Education, 1(1), 2016. 2430.

[22] Gomez-Mejia, L. R. et. a.. Managing Human Resources. USA: Pearson Education, Inc., publishing as Prentice Hall. 2012.

[23] Bangun Wilson. (n.d.). Manajemen Sumber Daya Manusia. Bandung: Erlangga.

[24] Chen, J. C., Silverthome, C., \& Hung, J. Y.Organization communication , job stress, organizational commitment, and job performance of accounting professionals in Taiwan and America.2016.

[25] Pincus, D.. Communication Satisfaction, Job Satisfaction and Job Performance, 1. http://doi.org/10.1111/j.1468-2958.1986.tb00084.x.b 1986. 